\title{
EN TORNO A LOS CONCEPTOS DE UNANIMIDAD Y MAYORÍA EN EL CONTRATO SOCIAL DE J. J. ROUSSEAU
}

CARLOS GARRIDO LÓPEZ

Universidad de Zaragoza 
SUMARIO

I. La Legitimidad COMO OBJETIVO.-II. Unanimidad Y MAYORIACOMO LEGíTIMOS MEDIOS DE EXPRESIÓN DE LA VOLUNTAD GENERAL.--III. LAS CONTRADICCIONES DEL MODELO PROCEDIMENTAL.-1. La admisición del consentimiento tácito para adherirse al contrato y aprobar la legis/ación.-2. La persistencia del egoísmo humano en la sociedad del contrato.-3. El pueblo soberano como "multitud ciega" que precisa de líderes.-4. La Ley de la mayoría en los sufragios como sustituto inadecuado de la supuesta unanimidad subyacente.-IV. A MODO DE CONCLUSIÓN. 
Revista de Derecho Político, núm. 41, 1996, pp. 215-247

\section{EN TORNO A LOS CONCEPTOS DE UNANIMIDAD Y MAYORÍA EN EL CONTRATO SOCIAL DE J. J. ROUSSEAU*}

POR

CARLOS GARRIDO LÓPEZ

Universidad de Zaragoza

\section{LA LEGITIMIDAD COMO OBJETIVO}

Para J.J. Rousseau, la política es algo más que una simple elaboración técnica, mucho más que la afanosa búsqueda de una adecuada forma de gobierno. En su construcción, lo político, cuya primacía no se discute, está dotado de un profundo sentido ético que conecta con la esencia del sistema social. $Y$ es que, como se apresura a poner de manifiesto en las primera páginas del Contrato, su propósito no es otro que indagar el auténtico fundamento del orden colectivo. Un orden establecido sobre los verdaderos principios de derecho político o reglas de administración legítima que, precisamente por estar adornadas de tal adjetivo, confieran la necesaria solidez a un tránsito hasta el momento considerado inicuo: el tránsito del hombre que, habiendo nacido libre, se halla, no obstante, socialmente encadenado.

De lo anterior, se deduce facilmente que la auténtica clave del Contrato, el axil de su análisis teórico, es el problema de la legitimidad política. y lo es, en opinión de Derathé ${ }^{1}$, no tanto porque contenga la denun-

* La presente nota está basada en el trabajo de investigación que, bajo el mismo título y dirigido por el Prof. Manuel Ramirez, fue defendido en diciembre de 1992 en la Facultad de Derecho de la Universidad de Zaragoza.

1 R. DERATHE, "Introductions", en J.J. Rousseau, (Euvres complètes, III Du contrat social. Écrits politiques, Bibliothèque de la Pléiade, Gallimard, París, 1964, CIV. 
cia de un determinado modelo social, cuanto porque en él se investiga y propone la naturaleza y los fundamentos de la autoridad política considerada legítima. Aquella que, siguiendo la célebre definición de Habermas $^{2}$, merezca el reconocimiento de los ciudadanos sometidos a ella al preservar su dignidad y autonomía.

Por ello, no resulta extraño que Rousseau, con los iusnaturalistas y Locke, comparta la premisa del consenso como causa de la autoridad estatal. Pero si importante es para el ginebrino constituir el Estasdo sobre esa adecuada base, más lo es, sin duda, conservar en su cotidiano devenir las circunstancias originarias que la hicieron posible. Es decir, que, admitido el origen convencional del poder la igualdad de los pactantes, la libertad individual $y$, sobre todo, el vínculo psicológico-espiritual de cuantos individuos consientan el contrato, deben permanecer como inexcusables constantes para su posterior fundamento legítimo. $Y$ de tal forma, que asentado sobre ellas surja de nuevo el consenso. En este caso, considerado condición formal para la persistencia del cuerpo político que, de mantenerse, permitiría descubrir, tras cada deliberación pública y en cada decisión colectiva que la Asamblea adopte, lo que el autor denomina volonté générale. Metafísica expresión volitiva dotada de una honda dimensión liberadora. Manifestación soberana de ese vínculo colectivo y permanente que precisa la participación de todos. Pero, ¿cómo conocer esta voluntad que aglutina el sentir de todos los corazones? ¿acaso se manifiesta de modo claro en algún momento?, y si así es, ¿bajo qué formas o procedimientos?

Para J. Habermas, lo característico del Contrato es que en él se mezclan la introducción de un nuevo principio de legitimación con propuestas tendentes a la institucionalización de un orden justo. En su opinión, que suscribimos plenamente, Rousseau inaugura «el tipo procedimental de legitimidad" (subrayado en el original) en el que la fuerza $y$ eficacia del modelo propuesto dependen, a la postre, de los procedimientos sugeridos para responder a los interrogantes anteriormente formulados. De lo que se trata en el mencionado tipo, "es de encontrar mecanismos que puedan fundamentar la suposición de que las instituciones básicas de la sociedad y las decisiones políticas fundamentales hallarían el asentimiento voluntario de todos los afectados si éstos pudieran participar -en libertad e igualdad-en los procesos de formación discursiva de la voluntad ${ }^{3}$.

2 "Legitimidad significa el hecho del merecimiento de reconocimiento por parte de un orden político". J. HABERMAS, La reconstrucción del materialismo histórico, Taurus, Madrid, 1981, pág. 243.

3 Op. cit., págs. 251 y 252. 
Pues bien, en el modelo procedimental roussoniano, y a pesar de su aparente contradicción, son la unanimidad y la mayoría en los sufragios los instrumentos elegidos para lograrlo. Ambos conceptos permiten expresar la volonté générale y conferir el necesario dinamismo al cuerpo político recién fundado. Pero, como veremos, no revisten igual transcendencia. Su significación axiológica es manifiesta y cualitativamente distinta. $Y$ es que, el ginebrino, en su personal empeño de dotar de legitimidad a las decisiones colectivas y al sistema político en su conjunto, concibe la decisión unánime como genuina manifestación de la voluntad general. Lo cual es lógico, ya que, para él, la ley debía ser la expresión colectiva de un íntimo y espontáneo sentimiento, y la libertad, "la obediencia a la ley que uno mismo se prescribe" ${ }^{4}$.

No obstante, sin desnaturalizar el anterior aserto y sólo cuando la unanimidad no surja espontáneamente en la Asamblea, Rousseau permitirá que la decisión colectiva pueda adoptarse por mayoría. En estos casos, la unanimidad real es abandonada por conveniencia, pero se mantiene como exigencia ideal cuyo supuesto trasunto es el resultado mayoritario. La resolución así tomada será considerada legítima y obligará igualmente a todos; incluso a los disidentes, pues se presume que, una vez conocida ésta, dejarán de serlo. Y ello, porque su íntima voluntad, a la postre, no difiere de la del mayor número. De lo cual puede deducirse que el principio mayoritario que el ginebrino introduce en su discurso carece de fundamentación valorativa propia, no siendo, en definitiva, sino un elemento ancilar de la unanimidad subyacente. Un sucedáneo sólo operativo e idóneo en la medida en que expresa la voluntad y el interés comunitarios. De lo contrario, y carente de contenido cierto, deviene en simple recurso técnico para la adopción de decisiones colectivas privadas de la necesaria legitimidad.

Al análisis teórico de los dos mecanismos descritos, junto al estudio de las aporías y tensiones que, en nuestra opinión, conlleva su funcionamiento, vamos a dedicar el nucleo central de este trabajo, tras el cual sólo restará extraer una conclusión. Y si la clave de la propuesta procedimental de legitimidad residía en el énfasis puesto sobre las condiciones necesarias para la formación del consenso, ésta conclusión no podrá ser sino el fracaso práctico, y acaso inevitable, de su autor al proponer un modelo excesivamente especulativo imposible de funcionar en la realidad.

4 El Contrato social, Libro I, Cap. VIII. Se cita edición castellana de Taurus, con prefacio de D. Enrique Tierno GaLván, Madrid, 1969. También hemos utilizado el texto original con introducción, notas y comentario de Maurice HaLBWACHS, Bibliothèque philosophique, Aubier, Editions Montaigne, París, 1943, por lo que a partir de ahora citaremos en nota las páginas de ambas ediciones. En el caso concreto, y respectivamente, pág. 30; Halbwachs, pág. 115. 


\section{UNANIMIDAD Y MAYORÍA COMO LEGÍTIMOS MEDIOS DE EXPRE- SIÓN DE LA VOLUNTAD GENERAL}

Si, en opinión de Rousseau, todos los hombres son libres e iguales por naturaleza, difícilmente podrian estar sometidos a obediencia alguna no aceptada previamente por todos y cada uno de ellos. De ahí, que ni la autoridad patriarcal, ni el "derecho" de más fuerte, ni la teoría de la esclavitud consentida, constituyan razones suficientes para que el hombre las considere legítimas. Siguiendo la tradición del realismo político, en todas ellas se establece el derecho partiendo de los hechos. Para nuestro autor, se trata más bien - como recuerda Bobbio- de todo lo contrario: "del primado de las leyes como fuente de derecho, como principal fuente de dominio" " ${ }^{5}$. Entendiendo estas leyes como la máxima expresión de la voluntad soberana. Fruto, en suma, de las convenciones, consideradas "base de toda autoridad legítima entre los hombres» ${ }^{6}$, y consecuencia, a su vez, de una originaria y transcendental convención: el contrato social. Pero no cualqueir tipo de contrato.

Como es sabido, en el modelo roussoniano no se preconiza un simple acuerdo entre individuos en virtud del cual éstos se someten a un gobierno determinado. La propuesta es mucho más ambiciosa y compleja. Así, por un lado, y al objeto de reducir al mínimo la enajenación de libertad que el hombre siempre sufre tras asociarse con los miembros de su especie, el ginebrino nos sugiere la celebración de un convenio en el que "cada uno, uniéndose a todos, no obedezca, sin embargo, más que a sí mismo y quede tan libre como antes"' '. O dicho de otra manera, una forma de asociación en la que se introduzcan todas las garantías que derivan de una sociedad unánime. Garantías de las que el ulterior funcionamiento del modelo precisa, y que, en nuestra opinión, pueden resumirse en la siguiente: que toda decisión colectiva obligatoria adoptada en la asamblea sea al mismo tiempo decisión del individuo. En suma, un sistema consensual que consagre la «libertad de autodeterminación" a la que R. A. Dahl se ha referido recientemente ${ }^{8}$. Auténtica libertad civil, por la cual, el futuro ciudadano, sólo deberá obediencia a la ley cuando su voluntad sea parte constitutiva de la misma.

5 N. Bоввіо, "Gobierno de los hombres o gobierno de las leyes", en El futuro de la democracia, Fondo de Cultura Económica, México, 1986, págs. 124 y 125.

- Contrato social, Libro I, Cap. IV. pág. 19; Halbwachs, pág. 70.

Ibidem, Libro I, Cap. VI. pág. 25; Halbwachs, pág. 90.

8 R.A. DAHL, Democracy and its critics, Yale university Press, New Haven, 1989. Se cita edición en castellano de Paidós lbérica, Barcelona, 1992, págs. 110 y sigs. 
Rousseau, empero, plenamente consciente de la insuficiencia de este planteamiento, decide dar un paso más. Lo natural del hombre, su libertad e igualdad, deben conservarse tras el pacto, por supuesto. Pero para que la asociación civil legítima surja y, lo que es más importante, pueda persistir como realidad independiente de los miembros que la componen, resulta precisa la transformación de este hombre en un uauténtico" ciudadano. Un patriota capaz de llevar dentro de sí la totalidad del espiritu colectivo ${ }^{9}$.

Ello explica que, por otro lado, y en contradicción con el axioma anterior, el ginebrino afirme que las cláusulas del contrato, bien entendidas, se reducen a una sola: "la enajenación total de cada asociado con todos sus derechos a toda la comunidad " ${ }^{10}$. Sin embargo, la teórica contradicción resulta sólo aparente. La alienante cláusula conlleva una entrega total y sin reserva al ser colectivo, pero no excluye el principio de la libertad y el requisito del consentimiento. Al contrario. Para el ginebrino, su proyecto liberador está dotado de una suerte de «alquimia mística" ${ }^{11}$ que permite conciliar la unidad y totalidad del individuo con su función social de parte, y al mismo tiempo, proteger la unidad $y$ totalidad social del riesgo de destrucción que la autonomía de las partes conlleva. De ahí la inextricable formulación del "compromiso recíproco» que el ciudadano debe contraer consigo mismo. Un doble compromiso ( $\ldots . .$. como miembro del soberano respecto a los particulares y como miembro del Estado respecto del soberano" ${ }^{12}$ ) cuya primera y más importante secuela es la volonté générale. Valioso instrumento roussoniano que, siendo expresión del íntimo consenso surgido tras el pacto, integra todas las voluntades y da vida al perfecto cuerpo político: aquel que, en palabras de Lopez Calera, consigue limitar en su seno la "parcialidad inauténtica de lo individual y la parcialidad "anorgánica" de lo social»" ${ }^{13}$.

Ciertamente, el término "voluntad general" no era novedoso en la teoría política. Como ha recordado S. Hoffmann, éste ya venía utilizándose por la doctrina en un sentido teológico, primero, y jurídico-político, después. La originalidad del ginebrino no se encuentra, por lo tanto, en

9 Vid. G. BuRdeAu, «Le citoyen selon Rousseau», en Études sur le Contrat social de J.J. Rousseau, publicatios de l'Université de Dijon, t. XXX, Société des Belles Lettres, París, 1964, pág. 223.

${ }^{10}$ Contrato social, Libro, I, Cap. VI, pág. 26; Halbwachs, pág. 90.

1 Vid. S. Hoffmann, "Du Contrat social ou le mirage de la volonté générale", en Revue internationale d'Histoire politique et constitutionnelle, $t$. IV, $\mathrm{n} \times 16$, 1954, pág. 296.

${ }_{12}$ Contrato social, Libro I, Cap. VII, pág. 27; Halbwachs, pág. 104.

13 N. M. a López Calera, Yo, el Estado. Bases para una teoría sustancializadora (no sustancialista) del Estado, editorial Trotta, madrid, 1992, pág. 83. 
la formulación del concepto, pero sí, y absolutamente, en las intenciones que le animan a la redefinición del mismo. $Y$ es que su declarado objetivo, a diferencia de los autores precedentes, es la superación de la más radical antítesis política, la fusión definitiva entra la libertad y la autoridad.

Para lograrlo, Rousseau asume indicutidamente dos postulados filosóficos - la moralidad de la razón y la uniformidad de las conciencias y preferencias- de cuya combinación obtiene la aludida y taumatúrgiga volonté générale ${ }^{14}$. Síntesis volitiva de opiniones individuales que dotará de dinamismo al Estado, conduciéndolo de modo claro e inequívoco a la "común conservación y al bienestar general» ${ }^{15}$. Voluntad única que deberá ser general tanto en su objeto como en su esencia, $y$, además, partir libre y espontáneamente de todos y cada uno de los asociados, convertidos, tras el pacto, en átomos homogéneos: "psicológicamente uniformes, socialmente iguales, jurídicamente ligados por lazos mutuos» ${ }^{16}$.

De ahí la distinción, aparentemente contradictoria, entre la volonté générale y lo que el ginebrino denomina volonté de tous ${ }^{17}$. Conceptos que, como ha señalado la práctica totalidad de la doctrina, no deben nunca confundirse. Y ello, porque frente a la simple suma, una por una, de las opiniones particulares de los ciudadanos, la voluntad general se configura como un imperativo categórico que expresa la homogeneidad de la especie humana. Una noción definida más moral que empíricamente, previa a cualquier decisión y siempre presente en la Asamblea ${ }^{18}$. La voluntad de la comunidad, en suma, y no la voluntad de los particulares que componen esa comunidad ${ }^{19}$. Lo que no quiere decir que ámbas sean

14 Vid. S. Hoffmann, "Du Contrat social ou le mirage de la voonté générasle», ya cit, págs. 289 y sigs.

${ }_{15}$ Contrato social, libro IV, Cap. I, pág. 109; Halbwachs, pág. 361.

16 S. Hoffmann, "Du Contrat social ou le mirage de la volonté générale", ya cit, pág. 302. (La traducción, en este caso, como en las sucesivas obras francesas citadas y no traducidas al castellano, corresponde al autor. ).

17 Vid. Contrato social, Libro II, Cap. III, pág. 38 y 39; Halbwachs, pág. 145. Un detenido análisis de la mencionada distinción, puede encontrarse en la yá clásica obra de B. Groethuysen, Jean-Jacques Rousseau, 8ème ed., Gallimard, París, 1949, págs. 71097.

${ }_{18}$ Como bien dijo G. del VECCHO, «el contrato social no se refiere en absoluto a la voluntad y a la conciencia empiricas sino a la voluntad y a la conciencia trascendentales". "Des caractères fondamentaux de la philosophie politique de Rousseau", en Revue critique de législation et de jurisprudence, 1914, págs. 311312, citado por G. Bundeau, Traité de Science Politique, II, L'Etat, Deuxième édition, Librairie générale de droit et de jurisprudencie, Paris, 1967, pág. 69.

19 Significativo ejemplo de confusión puede verse, no obstante, en R. CarRé de Malberg, Contribution à la théorie générale de l'État, t. II, Sirey, París, 1922, págs. 
siempre dos voluntades distintas, sino que pueden serlo, que, en algún momento, pueden no coincidir. De ahi que, para J.J. Chevalier ${ }^{20}$, lo que entre ellas existe es una diferencia de naturaleza, pero no de grado. En otras palabras, que obteniéndose de idéntico modo, el sentido de las mismas diferirá o no en función del espíritu que anime los corazones. Si la declaración de voluntad inferida del cómputo de voluntades individuales adornadas por la vertu ${ }^{21}$ tiene como objetivo el bienestar común, el resultado será la volonté générale. Por contra, si la totalidad de las voluntades individuales están animdas por intereses egoistas o particulares, de su cómputo no se obtendrá la voluntad general, sino la despreciable voluntad de todos ${ }^{22}$.

De admitir plenamente el sentido roussoniano de esta importantísima distinción, el principal reto para el mantenimiento del cuerpo político será - como ha dicho Riley ${ }^{23}$ - el de generalizar la voluntad excluyendo todo "particularismo"; pero como es lógico, sin anular la libertad del individuo, sin destruir la particularidad. Arduo problema, ya que, a pesar de la metafísica formulación del concepto que el ginebrino realiza, no le basta, por las razones que acabo de aludir, con su presencia inmanente, en abstracto. Por el contrario, una vez constituido el Estado, y pese a que

154 y sigs. Para un análisis de la misma, vid. G. Bacot, Carré de Malberg et l'origine de la distinction entre souveraineté du peuple et souveraineté nationale, Editions du CNRS, París, 1985, págs. 20-26.

${ }_{20}$ J. J. Chevalier, Los grandes textos políticos (Desde Maquiavelo a nuestros dias), Aguilar, Madrid, 1974, págs. 149 y 150. (Se cita séptima edición, siendo la primera en castellano de 1954). En el mismo sentido puede consultarse su trabajo "Jean-Jacques Rousseau ou l'absolutisme de la volonté générale", en Revue Française de Science Politique, vol. III (1), 1953, págs. 5 y sigs.

21 Sobre el concepto de vertu, vid. IRING FetSCHER: «Filosofía moral y política en j.J. Rousseau", en Revista de Estudios Políticos (nueva época), no 8, monográfico sobre Rousseau, 1979, págs. 19-32.

22 Aceptar esta dicotomía conceptual supone, evidentemente, reconocer que existe o puede existir una voluntad del cuerpo político diferente a la suma de las voluntades de los individuos que lo componen. Extremo roussoniano que, por ejemplo, L. DuguIT, no está dispuesto a admitir, ya que, en su opinión, «...nada prueba que de este concurso de voluntades nazca una voluntad distinta de las voluntades individuales concurrentes (...) esto no está demostrado y es indemostrable" (Traité de Droit Constitutionnel, tome prémier, Ancienne Librairie Fontemoing, París, 1927, pág. 582). Y como él, la mayor parte de los autores que, de Benjamin Constant a nuestro días, se han aproximado al Contrato desde una perspectiva liberal. Para todos ellos, la cuestión era más sencilla. Bastaba reunir a los ciudadanos o a sus representantes e inquirir su deseo. El resultado, lógicamente relativo, no constituiría artificio volitivo alguno, sino el conjunto contrastado de intereses múltiples $y$ divergentes.

${ }_{23}$ P. RiLeY, The General Will before Rousseau, Princeton University Press, 1986, pág. 249. Citado por N. M. López Calera, Yo, el Estado..., ya cit., pág. 86. 
la generalidad de la volonté sólo estaría asegurada por esa relativa abstracción, renuncia a ella y afirma que la voluntad general debe ser interrogada en todos los casos. Pero dado que el bien común, objeto de ésta no siempre aparece fácilmente a los ojos del pueblo, se impone a tal efecto la necesidad de algún procedimiento operativo que facilite su conocimiento.

Pues bien, en el modelo roussoniano, es el voto el instrumento elegido para lograrlo. Recurso eminentemente técnico que, una vez reunida la Asamblea e impulsados -en teoría - todos sus miembros por idéntico interés, permite inferir de su concurso la volonté générale. La razón de tal catársis colectiva reside en la misma concepción del sufragio individual. Y es que éste, se nos presenta en el Contrato como la respuesta correcta de cada ciudadano a la "pregunta correcta" que a sí mismo debe plantearse. Pregunta que, en opinión de B. Barry, puede expresarse en los siguientes términos: "¿Qué medida me beneficiará junto con todos los demás, en lugar de beneficiarme a costa de todos los demás? " ${ }^{24}$. En tales condiciones procedimentales, sometido un objeto a consulta, el resultado de la misma sumados los votos deberá ser unánime. El beneficio colectivo, moralmente descubierto por cada miembro del soberano al contestar la cuestión clave, habrá unificado las voluntades al unificar las conciencias. La unanimidad en los sufragios se convierte, de esta forma, en genuina manifestación de la voluntad general. La coherencia del modelo, la legitimidad de las decisiones colectivas, el contenido del contrato, en suma, así lo imponen. Como asimismo lo reconoce expresamente el autor en las páginas de su obra ${ }^{25}$.

Ocurre, no obstante, que para que las decisiones políticas sean legítimas no basta con un resultado unánime. La razón es simple: la unanimidad por sí sóla, como resultado mecánico y casual, acaso no difiera de esa voluntad coincidente de todos de la que anteriormente habláramos. Como es sabido, lo que generaliza la voluntad en la Asamblea «no es tanto el número de votos como el interés común que les aúna» ${ }^{26}$. De ahí que, faltando éste la unanimidad obtenida resulte, en el mejor de los casos, sospechosa. Suspicacia fundada, sin duda, pues las expresiones

24 B. BARry, "El interés público", en Anthony Quinton (coord.), Filosofía Política, Fondo de Cultura Económica, México, 1974, pág. 186.

${ }^{25}$ "Cuanto más reina el concierto en las asambleas, cuanto más se acercan los acuerdos a la unanimidad, más dominante es la voluntad general" (Contrato..., Libro IV, Cap. II, pág. 111; Halbwachs, pág. 366). Y también, a sensu contrario, cuando habla de la degradación del estado y la identifica con la situación social en la que "la unanimidad ya no reina en los votos; la voluntad general no es la de todos" (Contrato..., Libro IV, Cap. I, pág. 110; Halbwachs, pág. 362).

${ }^{26}$ Ibidem, Libro II, Cap. IV, pág. 42; Halbwachs, pág. 155. 
unánimes pueden no ser la adecuada respuesta a la adecuada pregunta, sino manifestación electoral de la violencia, el interés egoísta o el miedo. $Y$ asi lo recalca el propio Rousseau, al advertir que tras periódicas e incondicionales adhesiones plesbicitarias con frecuencia se encuentran auténticos monopolios de poder, sustentados, a su vez, por las más diversas técnicas de manipulación de la voluntad ${ }^{27}$.

Para el ginebrino, por el contrario, el único acuerdo legítimo concebible como tal deberá ser fiel reflejo de la voluntad y el interés del cuerpo político. Un resultado espontáneo y común, basado más en el consenso de corazones que en el de argumentos, ajeno a cualquier tipo de deliberación y contraste de opiniones. Fruto, a la postre, del carácter absoluto del contrato, de la identidad espiritual de los pactantes ${ }^{28}$.

Por lo expuesto, parece que, en el modelo roussoniano, la regla de la unanimidad se propone, si bien con reservas, como el mecanismo apropiado para superar la tensión entre el todo y las partes. Como la máxima garantía con que el ciudadano cuenta, que le induce a ceder voluntariamente su bien más precioso, la libertad natural, por otra libertad, ciertamente paradójica, que debe suponer la anulación del interés individual y su completa comunión en el Estado ${ }^{29}$.

Pero si el consenso en la medida en que exprese la voluntad general deviene abstractamente como el objetivo legitimador, en la prácti$\mathrm{ca}$, éste resulta las más de las veces inaccesible. Como el autor reconoce, sólo el pacto social exije por naturaleza un consentimiento unánime ${ }^{30}$. Sin embargo, incluso en este instante y ante la dificultad que el asenso total entraña, admite la existencia de opositores al contrato. Oposición que, en todo caso, no lo invalida, ya que los disidentes quedan fuera del mismo al ser considerados como extranjeros entre los ciudadanos.

27 Vid. Ibidem, Libro IV, Cap. II, págs. 11 y 112; Halbwachs, pág. 367.

${ }^{28}$ Vid. B. GROETHUYSen, Op. ciot., págs. 99 y sigs. y G. Burdeau, "le citoyen seIon Rousseaun, ya cit., págs. 222 y 223.

29 Como L. Althusser puso de manifiesto, lo que el autor del Contrato intentaba con su fórmula era alcanzar la interioridad de la alienación de cada individuo. $O$ lo que es lo mismo, y frente a la alienación total en la exterioridad de Hobbes, la alienación total en la interioridad. Vid. "Sobre el Contrato Social", en C. Lévi-Strauss y otros, Presencia de Rousseau, Nueva Visión, Buenos Aires, 1972, págs. 80 y sigs.

3o No obstante, y en plena coherencia con su modelo, Rousseau considera que, además del pacto social, existe otra ley del Estado en la que el concurso de todas las voluntades resulta requisito indispensable. Se trata, lógicamente, de la reforma o revocación del pacto originario, cuya exigencia de unanimidad se apunta en el Contrato Social, Libro III, Cap. XVIII, y se precisa en Consideraciones sobre el gobierno de Polonia. 
Con posterioridad, instituido el Estado, la exigencia de unanimidad real parece relativizarse. $Y$ aunque el consenso como clara manifestación de la voluntad general debiera surgir en cada acto legislativo, Rousseau admite que no siempre es necesario. A menudo incluso imposible. Consciente del pluralismo social ${ }^{31}$, y en ausencia de acuerdos unánimes, sugiere la ley de la mayoría en los sufragios como único medio capaz de evitar la behetría y conferir dinamismo al cuerpo político. Pero... ¿de dónde surge la legitimidad de tal ley? ¿En dónde residiria la obligación de los menos de someterse a los más?

En palabras del autor del Contrato, la ley de la mayoría ues en sí misma el establecimiento de una convención, y supone, al menos una vez, la unanimidad" ${ }^{32}$. Esta afirmación, empero, no implica necesariamente, como en el caso de Locke, que la regla de la mayoría deba ser aceptada de forma expresa por el pueblo ${ }^{33}$. Rousseau, acaso más cauto en este punto que el pensador inglés, considera dicha regla como una consecuencia del propio contrato fundacional. Y así, como "secuela" de éste, se impone la voz del mayor número que, en el futuro, y en defecto de unanimidad, decidirá las cuestiones colectivas ${ }^{34}$. Consumado el pacto, la mayoría, legitimada como decimos por el asenso de todos hacia aquél, pierde convencionalmente su carácter de fracción social para transformarse en guía colectivo. Lo que, en coherencia con el modelo descrito, no es sino una radical contradicción -como veremos, sólo aparente para su autor- de los principios del mismo.

Como ha sido puesto de manifiesto, lo que induce a los individuos a consentir en la creación de un cuerpo político, es la garantía de que nin-

${ }^{31}$ Un upluralismo", no obstante, respetuoso por definición con la ortodo$x i a$ fundacional y -como entre nosotros ha recordado. A. HERMOSA ANDUJAR- ajeno a la estructural particularización de los intereses humanos y a la legitimidad de esa particularización, sustento del auténtico pluralismo. «El camino de Rousseau. De la democracia directa a la democracia representativa", en Revista de Estudios Políticos (nueva época), no 50, 1986, pág. 101.

32 Contrato social, Libro I, Cap. V, pág. 24; Halbwachs, pág. 86.

${ }^{33}$ Recordemos que para LOCKE, "... lo que origina y de hecho constituye una sociedad política cualquiera, no es otra cosa que el consentimiento de una pluralidad de hombres libres que aceptan la regla de la mayoría y que acuerdan unirse e incorporarse a dicha sociedad". Segundo Tratado sobre el Gobierno Civil, Alizanza, Madrid, 1990, cap. 8, (99), pág. 114. Una aproximación al concepto de mayoría en Locke puede encontrarse en W. KENDALL, John Locke and the Doctrine of Majority Rule, Urbane: University of Illinois Press, 1941, interesante obra que debe ser leida no sin cierta cautela pues, en nuestra opinión, el autor inglés dista mucho de ser - como estima Kendall- un defensor convencido del principio de la mayoría. Si lo acepta es por pura conveniencia $y$, al igual que Rousseau, con no pocos recelos, motivados, en su caso, por el necesario respeto a los inalienables derechos del individuo.

${ }^{34}$ Vid. Contrato social, libro IV, Cap. II, pág. 112; Halbwachs, pág. 368. 
guno deberá obediencia salvo a la ley que a si mismo se haya dado. Garantía que, de aceptar la lógica que el principio mayoritario lleva consigo, se habrá desvanecido. Un miembro de la mayoría ganadora podrá obedecer y seguir siendo libre; pero no el de la minoria, que se verá compelido a acatar una ley aprobada por otros. La libertad de éste último, entendida como autogobierno, y el teórico consenso en el que confió al consentir el pacto estarán, desde ese momento, seriamente dañados. $Y$ así parece verlo el mismo Rousseau cuándo retóricamente se pregunta: «... ¿cómo un hombre puede ser libre y estar obligado a conformarse con voluntades que no son las suyas? ¿Cómo los que se oponen son libres y sometidos a leyes que no han consentido?" ${ }^{35}$.

El ginebrino podía responder que existió una convención donde tal posibilidad quedó admitida expresamente por todos. O, también, sugerir la existencia de un compromiso justo, en el sentido que P. Singer confiere a tal expresión ${ }^{36}$. Incluso podía decir que, por el pacto, el cuerpo politico constituye una unidad objetiva cuya voluntad coincide siempre con la del mayor número. Para Rousseau, sin embargo, ninguna de estas opciones resulta suficientemente satisfactoria. Con ellas, el principio mayoritario adquiriría plena carta de naturaleza como principio autónomo. Extremo que, impulsado por una profunda obsesión legitimista, no está dispuesto a admitir. Los anteriores argumentos no le sirven, porque el concepto de mayoría que en ausencia de decisión consensual propone no implica el abandono de la sociedad unánime tan finamente construida. Lo que con él cesa es la exigencia de unanimidad real, como hecho; pero no como exigencia ética, como norte del modelo que, por contra, se mantiene.

Así las cosas, si una decisión mayoritaria se considera legítima, es porque la misma refleja la unanimidad subyacente deseada y no conseguida. Si el mayor número merece también mayor respecto, es porque expresa en esencia la voluntad y el interés del cuerpo moral ${ }^{37}$. Ya no se

35 Ibidem, Libro IV, Cap. II, pág. 112; Halbwachs, págh. 368.

36 Para P. SINGER, si el procedimiento mayoritario de toma de decisiones es el mecanismo moralmente más equitativo y legítimo de cuantos existen a tal fin, es porque se presenta como el paradigma de un compromiso justo entre las pretensiones concurrentes al poder. Compromiso benéfico que permite resolver pacíficamente las diferencias de opinión, las disputas, sin recurrir a la fuerza. Evidentemente, Rousseau, animado por la teórica pretensión de actuar en base a principios absolutos, hubiera rechazado tal argumento como degradante e incompatible con la sociedad del contrato. Democracy and disobedience, Oxford University Press, 1973, págs. 30 y sigs. Existe traducción al castellano de editorial Ariel, Barcelona, 1985.

${ }_{37}$ Vid. D. Negro Pavon, «Rousseau y los orígenes de la política del consenso", en Revista de Estudios Políticos (nueva época), no 8, 1979 , pág. 99. 
trata del clásico y conocido argumento de la fuerza, en virtud del cual el voto era la anticipación simbólica de la lucha. Ni siquiera de aquel otro, típicamente lockiano, de la fuerza del consentimiento ${ }^{38}$. De lo que se trata, textualmente, es de reconocer que " (...) todos los caracteres de la voluntad general están en la mayoría" ${ }^{39}$. De esta forma, y haciendo gala de un admirable malabarismo axiológico, Rousseau sugiere un sucedáneo del consenso tan idóneo como éste para alumbrar la voluntad general. La mayoría aparece como la representante natural de la comunidad y participa del sentido que posee la unidad del todo por encima de las partes. Pero no por su contenido y significado propio, sino por la útil presunción de que expresa razonablemente la volonté générale que debiera haber sido unánime ${ }^{40}$.

Con este argumento, el principio mayoriatrio queda en realidad huero. Pero es que el autor del Contrato, como se infiere de diversos fragmentos de su obra, no cree en la certeza y la bondad intrínseca del mismo. Si lo admite en su discurso es por lo que de operativo tiene, por lo que de indicio de unanimidad supone ${ }^{41}$.

${ }^{38}$ ".... como lo que hace actuar a una comunidad es únicamente el consentimiento de los individuos que hay en ella, y es necesario que todo cuerpó se mueva en una sola dirección, resulta imperativo que el cuerpo se mueva hacia donde lo lleve la fuerza mayor, es decir, el consenso de la mayorian. J. LOCKE, Segundo Tratado..., ya cit., Cap. 8 (96), pág. 112.

39 Contrato social, Libro IV, Cap. II, pág. 113; Halbwachs, pág. 369.

40 En este sentido, vid. S. HoffMANn, art. cit., págs. 298 y sigs., C. LeCLerCo, Le principe de la majorité, A. Colin, Collection "U», París, 1971, págs. 54063, y más extensamente, P. FAURE, "Unánimité et majorité dans le Contrat social de Jean-Jacques Rousseau", en Revue Française de Droit Public et de la Science Politique en France et à L'étranger, no 1, 1976, págs. 111-186.

41 Opinión radicalmente opuesta a la aquí expresada, mantiene en la doctrina española J. RuBio CARRACEDo, quien considera prejuicio bastante corriente la vinculación, a su entender errónea, de la unanimidad y la voluntad general. $Y$ es que esta última, en realidad, dado que los resultados unánimes son dudosamente fiables, se expresa de modo genuino por el sufragio de la mayoría. Rubio realiza tales afirmaciones considerando los primeros capítulos del libro cuarto, y no ciertas expresiones genéricas sobre la voluntad general que, siempre según él, puede inducir a error. Además, y apoyándose en autores como Barry y Levine, estima que la volonté y el interés público se pueden descubrir -e incluso, más que descubrir, "construir»- a través de la certeza procedimental que proporciona la regla mayoritaria. En su opinión, "todo parece indicar que Rousseau concibe la asamblea pública como una reunión de expertos que debaten imparcialmente un asunto de legislación hasta que una propuesta consigue el asentimiento de la mayoría y pasa, en consecuencia, a ser considerada como la solución correcta". ¿Democracia o representación? Poder y legitimidad en Rousseau, Centro de Estudios Constitucionales, Madrid, 1990, págs. 82 y sigs. 
A tenor de lo hasta ahora dicho, no resultaría extraño caracterizar el modelo como doctrina contra las minorías, pues parece evidente que la opinión de los menos, condenada siempre al fracaso, no reviste virtualidad alguna. $Y$ ello, a pesar de que el libre albedrio individual constituya una de sus máximas políticas. El ginebrino, salvará este grave escollo y dará respuesta al problema recurriendo, nuevamente, al ingenioso recurso de la presunción.

El razonamiento utilizado consiste en que la voluntad disidente del menor número en el fondo no es tal y, en último extremo, siempre coincide con la mayoritaria. Supongamos que tras el acto del sufragio la asamblea se divide. Por un lado, la mayoría, que expresa la voluntad general y decide la cuestión debatida. Por otro, la minoría, cuya opción es desechada de inmediato. La decisión resultante, sin embargo, es decisión de todos, ya que, de haberla conocido antes, todos hubieran consentido. En gráficas palabras de Rousseau, "cuando se propone una ley en la asamblea del pueblo, lo que se le pregunta no es precisamente si aprueba la proposición o la rechaza, sino si es conforme o no la voluntad general, que es la suyan. Y más adelante, continúa razonando en primera persona: "Aun cuando triunfe la opinión contraria a la mía, esto no quiere decir sino que me engañaba y que lo que se creía ser la voluntad general no lo era. Si mi opinión particular hubiese triunfado, hubiese hecho otra cosa de la que quería: no hubiese sido libre" ${ }^{42}$. De lo que puede deducirse que, en el supuesto hipotético de repetirse la votación, los menos, conscientes de su error, aceptarian iluminados la voluntad mayoritaria. Voluntad que al considerarse general era también la suya, aunque no la percibieran en primera instancia ${ }^{43}$. Por ello, la obligación del disidente a aceptar la postura del mayor número no supone en modo alguno coacción. Al contrario. Como J.L. Talmon puso de manifiesto ${ }^{44}$, la auténtica libertad roussoniana consiste en la capacidad que cada uno tiene de zafarse de sus propios intereses, preferencias y prejuicios, lo mismo personales que colectivos, que oscurecen la verdad y el bien objetivos, que si cada cual es sincero con su verdadera naturaleza, está forzado a querer. Con esta idea de libertad, y dado que la esencia de la voluntad general se encuentra también en la mayoría, cabe presumir que la minoría

42 Contrat social, Libro IV. Cap. II, pág. 113; Halbwachs, págs. 368 y 369.

${ }_{43}$ "... si se sometiera la decisión de la mayoría a un segundo escrutinio, la minoría, iluminada por lo que realmente es la voluntad general, votaría a favor de la proposición adoptada en la primera vuelta por la simple mayoría. La segunda vuelta vería aparecer la unanimidad. En la lógica de Rousseau, habría necesariamente unanimidad, es pues inutil recurrir a un segundo voto, podemos economizar la segunda vuelta". P. FAVRE, "Unanimité et majorité...", ya cit., pág. 141. 1956, pág. 45 .

${ }^{44}$ J.L. Talmon, Los orígenes de la democracia totalitaria, Aguilar, México, 
al expresar su opinión no ha conseguido ser plenamente libre, se he equivocado, ha tomado por voluntad general y bien objetivo algo que no lo es; por lo que se cumplirá deber fraterno para con los díscolos al instruirles en la verdad socialmente establecida ${ }^{45}$.

Verdad, en este caso mayoritaria, que, no obstante, y al igual que la unanimidad, debe surgir como sentimiento espontáneo y natural. Animada del interés público y el espíritu colectivo. Nunca resultado de prolongados debates y encendidas discusiones que, como Rousseau afirma en el Libro cuatro, Capítulo segundo de su obra, son anuncio del progreso de los intereses egoístas, de la división social, de la degradación y decadencia del Estado. Peligrosas tendencias que, de consolidarse, harían desaparecer la libertad recién conquistada, al convertir la otrora sacralizada opinión de los más en la peyorativa "voluntad de todos". llegítima, por tanto, al escindirse de la auténtica volonté, cuyo carácter absoluto es lo que, en palabras de Alf Ross, "salva a Rousseau de espectular sobre el intrincado problema de los poderes de la mayoría sobre la minorian ${ }^{46}$.

Hasta aquí, hemos podido comprobar cómo la regla mayoritaria era sugerida por el autor del Contrato como el instrumento o recurso procedimental más satisfactorio para manifestar la voluntad, teóricamente unánime, del cuerpo político. Pero... ¿qué tipo de mayoría es la propuesta a tal efecto? O en otras palabras, si ésta es el resultado de la suma de votos coincidentes, ¿cuántos son necesarios para formarla? Pues bien, en lógica coherencia con el constructo roussoniano, y aun cuando quepa una amplia gradación, sólo podrá ser considerada como mayoría legítima la comprendida entre la mitad más uno de los votos y la unanimidad menos uno. Un número de votos inferior a la mitad de los miembros de la Asamblea jamás podría representar esencialmente la voluntad general, pero entre la unanimidad y la igualdad "hay muchas divisiones desiguales, en cada una de las cuales puede fijarse ese número según el estado y las necesidades del cuerpo político" ${ }^{47}$. En concreto, y como el mismo Rousseau pone de manifiesto, las distintas proporciones

45 Con esta argumentación, dice J. J. CheValieR, "Rousseau consigue resolver la dificultad inherente a la regla de la mayoría, que Grotius, Puffendorff, Locke habian eludido, y eliminar de su sistema toda llamada incluso indirecta a la fuerza. Vemos como por el juego, o mejor por el milagro, de la voluntad general la ley, expresión de esta voluntad, puede a la vez emanar del hombre y no obstante estar por encima del mismo, por encima de toda voluntad humana individual, caprichosa, inestable, arbitraria». "J.J. Rousseau ou l'absolutisme de la volunté générale", ya cit., pág. 20.

${ }_{46}$ Alf Ross, ¿Por qué democracia?, Centro de Estudios Constitucionales, Madrid, 1989, pág. 55.

${ }^{47}$ Contrato social, Libro IV, Cap. II, pág. 113; Halbawchs, pág. 369. 
exigidas en los votos derivarán de la adecuada combinación de dos aspectos: la importancia y gravedad de las decisiones y la urgencia en la adopción de las mismas. Combinación y proporciones que, en todo caso, no fueron sugeridas en el Contrato, sino, a título de ejemplo y sin constituir una propuesta precisa, en Consideraciones sobre el gobierno de Polonia ${ }^{48}$.

En conclusión, la mayoría relativa queda excluida del modelo como ilegítima, pues estaría más próxima al disenso que al ideal unánime del que se pretendía fuera sustituta. Cosa que, por el contrario, no ocurre con la mayoría absoluta, que cuanto más cualificada, más cercana a la unanimidad, objetivo legitimador del constructo.

\section{LAS CONTRADICCIONES DEL MODELO PROCEDIMENTAL}

Como hace ya algunos años E. Martín López puso de manifiesto entre nosotros, el pensamiento roussoniano, más allá de cualquier otra consideración, se presenta como un "proyecto de acción política y socialı. Y precisamente por ser un proyecto teórico para la acción, su prueba de fuego debe consistir de modo preferente "en comprobar si, una vez puesto en marcha, conduce a las metas previstas o a otras más o menos alejadas de las previsiones de su autorn (subrayado en el original) ${ }^{49}$. Pues bien, si hasta aquí el constructo teórico-procedimental ideado por Rousseau resultaba coherente en apariencia y la trabazón lógica del mismo parecía irreprochable, es al intentar ponerlo en marcha - sugieriendo

48 En dicha obra se afirma: «Entre el veto, que constituye la mayor fuerza individual de que disponen los miembros del poder soberano, y que únicamente se ejercerá para las leyes verdaderamente fundamentales, y la mayoría, que es la menor y se aplica a las materias de simple administración, corre toda una escala de propuestas en base a la cual puede determinarse la preponderancia de las opiniones en razón de la importancia de las materias. Por ejemplo, cuando se trate de legislación pueden exigirse al menos los tres cuartos de los sufragios, los dos tercios en los asuntos de Estado, la mayoria simple en elecciones y otros asuntos corrientes y momentáneos. Esto no es más que un ejemplo con el que ilustrar mi idea, y no una propuesta precisa". Consideraciones sobre el gobierno de Polonia, Estudio preliminar y traducción de A. Hermosa Andújar, Tecnos, Madrid, 1988, pág. 104 y 105. En lengua francesa, vid. J.J. RousseAu, (OEuvres complètes, III,...ya cit., pág. 997).

49 E. Martin López, "Del egocentrismo originario a la comunidad contractual. Análisis de una quiebra lógica en Rousseaun., en Revista de Estudios Políticos (nueva época), no 8, 1979, págs. 128 y 129. 
mecanismos que lo hagan funcionar y remedios para evitar su parálisiscuando surgen tensiones del mismo. $Y$ es que en clara contradicción con algunas de las premisas ya formuladas, el ginebrino nos muestra con encomiable rigor intelectual las limitaciones y riesgos que residen en el corazón de sus propios principios axiológicos. Limitaciones, que van mucho más allá del gusto por la paradoja y del abuso de fórmulas esotéricas - frecuentemente disculpadas por parte de la doctrina- de que el ginebrino hace gala, y que, a la postre, ponen de manifiesto las aporías del modelo y su excesiva abstracción.

A nuestro entender y en cuanto al tema que nos ocupa, éstas pueden enunciarse como sigue:

\section{La admisión del consentimiento tácito para adherirse al con- trato y aprobar la legislación}

Es sabido que, para el autor del Contrato, la única fuente de derecho considerada legítima es la convención. Tanto el pacto originario, fundamento de toda existencia social, cuanto todas y cada una de las leyes o actos de legislación que tras él se adoptan, deben presentar, para ser reconocidos por los ciudadanos, la misma naturaleza convencional. De ahi, que el consentimiento constituya el elemento clave de la construcción política. Un consentimiento, que, como es lógico, debe conllevar una manifestación positiva de voluntad. Con todo, Rousseau va a disculpar en determinadas ocasiones la declaración expresa de la misma, admitiendo la posibilidad de que pueda deducirse de dos circunstancias: a) la residencia para adherirse al Estado, y b) el silencio para aprobar la legislación.

a) El contrato social que dio vida al cuerpo político implicaba la enajenación del individuo. Una enajenación -si bien racional y beneficiosa-que, por serlo, requería la libre disposición de los sujetos afectados; la adhesión incondicionada de todos los individuos que en aquel instante ideal habitaran el teritorio del futuro Estado. Ocurre, sin embargo, que una vez constituido éste, la vinculación social de los fundadores no obliga en modo alguno a sus descendientes. En palabras de Rousseau, "aun cuando cada cual pudiera enajenarse, no podría enajenar a sus hijos: ellos nacen hombres y libres, su libertad les pertenece, y nadie sino ellos pueden de ella diponern ${ }^{50}$.

50 Contrato social, Libro I, Cap. IV. pág. 20; Halbwachs, pág. 72. 
De extraer todas las consecuencias posibles de esta afirmación, el necesario consentimiento de los nuevos miembros hacia el pacto originario podría convertirse en un periódico e interminable plebiscito individual. La estabilidad de la sociedad política y su eficaz desarrollo estarían constantemente en juego. Para evitarlo, el ginebrino afirma textualmente que "el consentimiento está en la residencia; habitar el territorio es someterse a la Soberanía» ${ }^{51}$. Aserto de validez general que, como puntualiza a pie de página, sólo es predicable en un Estado libre como el descrito, pues de lo contrario "(...) la familia, los bienes, la falta de asilo, la necesidad, la violencia, pueden retener a un habitante en el país a su pesar, y entonces su estancia no supone su consentimiento al contrato o su violación” ${ }^{52}$.

Una duda surge de inmediato tras la lectura de estas palabras: ¿por qué en la sociedad del contrato de la sola estancia de un individuo se presume su consentimiento y adhesión? En un "Estado libre", cuya pertenencia ha sido voluntaria para todos hasta ahora, parece razonable que algunas de las circunstancias mencionadas - familia, bienes, necesidad-puedan existir igualmente en algún momento y retener a un hombre cualquiera a pesar suyo. En este caso, la permanencia en el territorio vendría determinada por los intereses aludidos, y no por el consentimiento que nunca existió. El Estado dejaría desde ese instante de ser «libre", la presunción sería ficticia, y la sociedad unánime estaría rota al contener en su seno algunos ciudadanos obligados a serlo. De lo que se deduce, que la figura del consentimiento tácito al pacto originario basada en la residencia es un recurso sumamente incierto para sobreentender la imprescindible y voluntaria adhesión colectiva ${ }^{53}$. Como también lo es el silencio, cuando de él se presume el asenso de los ciudadanos hacia un acto de legislación, o la coincidencia de una voluntad particular con la general.

b) Ya vimos en su momento que la pureza teórico-procedimental del modelo propuesto no sólo radicaba en la existencia previa e inmanente de la voluntad general. Era preciso, además, determinar el sentido

$51 \quad$ Ibidem, Libro IV, Cap. II, pág. 112; Halbwachs, págs. 367 y 368.

52 Ibidem, Libro IV, Cap. II, nota 2 de Rousseau, pág. 112; Halbwachs, pág. 368 (f).

${ }_{53}$ Menos dudosa sería, por ejemplo, una presunción basada en la participativa actitud del nuevo ciudadano en las tareas asamblearias. $Y$ es que, como afirma. P. SINGER, la periódica participación en los procedimientos colectivos de toma de decisiones - además de crear una obligación moral prima facie de aceptar los resultados-, puede entenderse como un "cuasi-consentimiento" hacia tales procedimientos, hacia las condiciones de legitimidad sobre los que éstos se asientan, y hacia las mismas cláusulas del contrato o convención. Op. cit. págs. 45 y sigs. 
de ésta. Hacerla operativa. Concretarla caso por caso y a través del único recurso capaz de hacerlo: el cómputo de tantos votos como miembros tuviera la asamblea. Un cómputo electoral, indispensable por tanto para la plena realización de la libertad de autogobierno. Pero indispensable, además, para un eficaz y prudente desenvolvimiento de la cosa pública.

Como es sabido, el autor del Contrato, en clara contradicción con su modelo, reconoce la persistencia de las inclinaciones egoístas en la voluntad humana. Penoso continuum no sólo predicable de un ciudadano cualquiera, sino también, y con mayor fundamento, de los magistrados o príncipes que rigen los detinos comunitarios. $Y$ es que, aun cuando en una legislación perfecta la voluntad individual de éstos sería nula, la del cuerpo al que pertenecen subordinada y la general dominante, Rousseau considera que la práxis conduce a la situación inversa, haciendo las voluntades "más activas a medida que se concentran" ${ }^{54}$. Precisamente para evitarlo, para escapar al vicio inherente a todo gobierno ${ }^{55}$, insiste en la muy periódica celebración de asambleas y reitera la democrática necesidad del rito electoral, del sufragio colectivo.

Sin embargo, abandonando de forma sorprendente la congruencia teórica del modelo y esa cautela política de la que en otros lugares del Contrato da sobrada muestra, afirma: "Esto no quiere decir que las órdenes de los jefes no puedan pasar por voluntades generales, en tanto que el soberano, dueño de oponerse, no lo haga. En caso parecido, del silencio universal se debe presumir el consentimiento del pueblon (subrayado nuestro) ${ }^{56}$.

54 Contrato social, Libro III, Cap. II, pág. 71; Halbwachs, pág. 255.

55 Para Torres del Moral, todas estas afirmaciones de tono "realista" (persistencia de voluntades egoístas, abuso del gobierno...) suponen la introducción de determinados aspectos del denostado "antimodelo» en el modelo. En sus palabras, "si el pacto inicial no ha sido un inmenso fraude, como lo fue el antipacto, no se nos alcanza a ver de dónde emerge esa propesnsión de ciertos individuos a prevalerse de su posición política para buscar su provecho particular a costa del general; no se percibe cómo, si la condición es igual para todos en toda coyuntura, nadie puede tener interés en hacerla onerosa para los demás, pues la estaría haciendo onerosa también para sí mismo, como tan brillantemente había expuesto el mismo Rousseau. (...) Si el pacto igualitario deseado no logra que gobernantes y gobernados coincidan, sean los mismos, es que ha fracasado su inicio. Más aún: si, admitido que haya unos y otros, no se ha logrado desvanecer el satánico afán de poder y la elitista psicología de quienes están en él o en sus aledaños, es que aquel pacto no fue lo que decía ser, es que no se celebraba en las condiciones requeridas de verdadera igualdad liberadora, es que dejaba de subsistir alguno de los males que aquejan a la sociedad opresora". Vid. "Modelo y antimodelo en la teoría política de Rousseaun, Revista de Estudios Políticos, no 212, 1977, pág. 145.

56 Contrato social, Libro II, Cap. I. pág. 36; Halbwachs, pág. 136. 
Rousseau, al admitir con estas palabras que el mutismo de los ciudadanos puede transformar una orden del caudillo en voluntad general, está equiparando de alguna manera la ausencia de manifestación soberana con el consentimiento tácito, y éste, a su vez, con la unanimidad legitimadora de toda obligación política. $Y$ es su obsesión legitimista por lograr el difícil consenso lo que le induce a ello. Como la unanimidad real resulta las más de las veces imposible, la presume. Pero con presunciones tan poco claras introduce en su argumentación un elemento altamente desestabilizador ${ }^{57}$.

Cierto es que el silencio del pueblo no implica que éste se haya obligado ex ante a consentir las órdenes del magistrado. De hacerlo, de entregarse el soberano en plena libertad, el compromiso de obediencia destruiría el cuerpo político. Sin embargo, la admisión del consentimiento tácito a posteriori convierte el instrumento esencial del modelo -el acto del sufragio- en accesorio, y la voluntad de todos y cada uno de los ciudadanos en superflua ${ }^{58}$. Pero es que, además, como el propio Rousseau reconoce, no existe forma humana de verificar la certeza de tal presunción si no es sometiéndola a la sanción de los sufragios libres del pueblo ${ }^{59}$. Operación con la que, como es obvio, desaparecería tanto el mudo carácter del supuesto asenso cuanto la utilidad de la contingente presunción.

En definitiva, admitir el consentimiento táctito en el modelo convertiría la voluntad general en pura especulación y podría generar, de utilizarse interesadamente por el príncipe, en un absoluto arbitrio. El proceso de usurpación y abuso propio de todo gobierno no habría hecho sino empezar.

57 $\mathrm{Ni}$ al mismo Rousseau se le escapa que el silencio del pueblo puede deberse tanto a un general asentimiento cuanto a la indiferencia, pasividad o miedo de los ciudadanos. Es más, incluso en otro lugar de su obra advierte del peligro que éste entraña, al señalar que el principe, bajo pretexto de acto sediciooso y pareciendo que sólo usa de sus derechos, puede fácilmente extenderlos e impedir las asambleas, "de suerte que se prevale de un silencio que impide romper" (Contrato social, Libro III, Cap. XVIII, pág. 107; Halbwachs, pág. 358).

${ }_{58}$ "Llevado por su sed de unanimidad - dice Fauvre-, Rousseau consiente en introducir en su sistema político lo que no está lejos de ser su contrario: el consentimiento tácito, consentimiento que, porque tácito, podrá ser considerado como unánime, pero que hace evidentemente la expresión de la voluntad popular muy aleatoria y al menos accesoria". Vid. "Unanimité et majorité...", ya cit., págs. 138 y 139.

59 Vid. Contrato social, Libro II, Cap. VII, pág. 51; Halbwachs, pág. 182. 


\section{La persistencia del egocismo humano en la sociedad del contrato}

Para Rousseau, autor dotado de una honda preocupación antropológica y fino observador de las sociedades de su tiempo, lo artificial de la naturaleza humana es el egoismo presente en la vida pública. Sentimiento relativo y facticio que induce al hombre civilizado a prestar más atención a sí mismo que a cualquier otro. Amour-propre, fruto de un contrato abusivo que, supuestamente fundado en la razón, ha bastardizado la libertad y todo lo natural que aún restaba socialmente ${ }^{60}$. Las cosas podían haber sido de otra manera, es cierto. Pero las erróneas bases sobre las que se asentó el orden social y su derecho, han terminado anulando las primeras y más simples operaciones del alma humana ${ }^{61}$.

Con todo, el ginebrino no se resigna al inicuo modelo existente. Es más, lo rechaza como única realidad posible. La vuelta a estado de naturaleza le resulta inverosímil, por supuesto. Pero la perfectibilidad del ser humano ${ }^{62}$, en la que confía, permite la construcción de un colectivo distinto. Una comunidad contractual cuya ética, lejos de identificarse con el egoísmo racional, subraye las emociones comunes. Cuya base común de sociabilidad sea el sentimiento. Sustituyendo en la conducta humana "la justicia al instito y dando a sus actos la moralidad de que antes carecían". Sólamente entonces -continúa Rousseau-, "sucediendo la voz del deber al impulso físico y el derecho al apetito, el hombre, que hasta el momento no habia atendido sino a sí mismo, se ve obligado a obrar teniendo en cuenta otros principios (...)" ${ }^{63}$. A partir de ese instante, siempre y cuando los "nuevos" hombres reunidos se consideren un sólo cuerpo no tendrán más que un interés y, por lo tanto, una sóla voluntad. Al fin, la permanente dialéctica social habrá cesado.

Sin embargo, y contradictoriamente con lo propuesto, el ginebrino admite que, incluso en la idealizada sociedad del contrato, el individuo se encuentra sometido a dos impulsos contrapuestos: la búsqueda de beneficio personal y la atracción desinteresada hacia la construcción del

60 Sobre la transformación del amour de soi, sentimiento natural, en amour propre, puede consultarse el trabajo de IRING FETSCHER Art. cit., págs. 14 y sigs.

${ }_{61}$ Vid. el Prefacio al Discurso sobre el origen y fundamentos de la desigualdad entre los hombres, edición de Jordi Beltrán, Alhambra, Madrid, 1985, págs. 60 y sigs. En lengua francesa, vid. J.J. Rousseau, (OEuvres complètes, III... ya cit., págs. 125 y sigs).

${ }_{62}$ Cualidad a la que Starobinski dedica especial atención a lo largo de su obra J.J. Rousseau; la transparencia y el obstáculo, Taurus, Madrid, 1983.

63 Contrato social, libro I, Cap. VIII. págs. 29 y 30; Halbwachs, pág. 114. 
bien público. Dualidad existencial que le confiere también doble dimensión volitiva. En otras palabras, que cada ciudadano acaso tenga un interês distinto del común y una voluntad particular distinta de la general que como ciudadano tiene.

Para Rousseau el soberano, al estar formado por particulares, no puede tener en buena lógica un interés contrario al suyo; pero sí podrán tenerlo los particulares respecto al soberano y considerar lo que deben a la causa común como una contribución gratuita ${ }^{64}$. En éste último caso, la participación del individuo en el sufragio, lejos de reflejar la espontánea coincidencia de su voluntad con la volonté générale, expresaría de nuevo su egoísmo.

Nos encontramos, evidentemente, ante un dilema de difícil solución. Por un lado, el ginebrino afirma que el interés del colectivo emana de los intereses particulares, y por otro, que los trasciende, que cuando éstos son viles, se sitúa por encima de los mismos. Idéntico dilema al que existía entre voluntad general y voluntad de todos. Y ello, porque, en realidad, la manifestación volitiva de los ciudadanos es la respuesta a una cuestión de intereses. Cuestión que para B. Barry, como vimos, podía expresarse del siguiente modo: ¿qué medida me beneficia junto con todos los demás, en lugar de beneficiarme a costa de todos los demás? Pues bien, si la pregunta ha sido autoplanteada de forma correcta y respondida honradamente, el modelo roussoniano funciona. Por contra, si el carácter absoluto y naturalmente independiente del individuo - que Rousseau defiende- implica la persistencia de intereses particulares eventualmente egoístas, el sentido de la pregunta puede invertirse ${ }^{65}$. ¿Cómo hacer hablar entonces a la voluntad general? Si el ciudadano, lejos de moralizarse plenamente, continúa poseido por su egoísmo, ¿cómo generalizar el interés común? Si lo que intenta es disfrutar "de los derechos de ciudadano sin querer llenar de deberes de súbdito" ${ }^{66}$, ¿no habrá fracasado acaso el tránsito a la idealizada comunidad contractual ? ${ }^{67}$

64 Vid. Contrato social, Libro I, Cap. VII, págs. 28 y 29; Halbwachs, pág. 107.

${ }_{65}$ Así lo admite expresamente, al afirmar que, en estos casos, la falta que el ciudadano comete "es cambiar el estado de la cuestión y contestar a otra cosa que a la que se le pregunta; en vez de decir: es ventajoso al Estado, dice: es ventajoso a tal hombre o a tal partido que tal cosa suceda". No obstante, a pesar de alterarse el sentido de la pregunta, y por lo tanto, también de la respuesta, nuestro autor considera que la voluntad general no se anula ni se corrompe. Por el contrario, e incluso subordinada a otras voluntades que se le imponen, siempre permanece "constante, inalterable y pura" en la conciencia de cada ciudadano y en la propia asamblea (Contrato social, libro IV, Cap. I, pág. 110; Halbwachs, pág. 363).

${ }_{66}$ Ibidem, Libro I, Cap. VII, pág. 29; Halbwachs, pág. 107.

67 En este sentido, véase especialmente E. MARTín LÓPEZ: art. cit., págs. 115 y sigs., quien, utilizando la célebre tipología de F. TönNIES, considera que un pacto 
En opinión de F. Rangeon, lo que en este punto existe es una insalvable contradicción que, a la postre, mina todo el edificio. $Y$ es que, «...o bien insistimos en el carácter unitario, absoluto e incontestable del interés público, a riesgo de cortar el cordón umbilical que le une al interés particular y de someter a los individuos a la opresión de la sociedad; o bien insistimos en la identidad específica del interés particular, base de todo el edificio, a riesgo entonces de reducir el interés público al simple resultado del conflicto de estrategias individuales" ${ }^{68}$. Rousseau no se decide, e intentando conciliar ambos extremos, consagra el peligroso carácter dicotómico de la voluntad individual y asamblearia.

Con tan inestable planteamiento teórico, la decisión colectiva sólo será legítima cuando los ciudadanos, al votar, consideren el bienestar común por encima de cualquier otro. Por contra, si gran parte del cuerpo político o su totalidad contempla en el momento del sufragio su propio capricho, la decisión resultante quedará viciada. Por mayoritaria o unánime que ésta sea, no reflejará sino la voluntad de todos resultado de una coyuntural coincidencia de intereses. Nunca la voluntad general, claramente eludida al orientarse hacia aspectos singulares.

Así las cosas, el problema estribaría en determinar cuándo nos encontramos en un supuesto y otro. Empresa inútil, pues si difícil resulta descubrir el impulso honesto en la opinión de un ciudadano, aún más, si cabe, concluir que todas o la mayoría de ellas son honestas, y que de la suma de esas dudosas opiniones pueda surgir finalmente la críptica voluntad general.

La paradoja axiológica es evidente. Tras un pacto como el propuesto en el que, se supone, el estado natural se reconcilia en un nuevo Estado, el recelo hacia el hombre carece de sentido. Si el contrato ha sido como debia ser, si se celebró en las condiciones requeridas de libertad e igualdad, lo artificial de la naturaleza humana hubiera desaparecido al mismo tiempo que el resto de los males de la sociedad opresora ${ }^{69}$. $\mathrm{Si}$,

como el descrito por Rousseau basado en actitudes interesadas que persisten tras el mismo, no puede conducir a la "comunidad" (Gemeinschaft), sino a la "sociedad" o ámbito societario (Gesel/schaft) con todas las consecuencias que tal apreciación doctrinal lleva consigo.

68 F. RANGeon, l'idéologie de l'intérêt général, Préface de Georges Vedel, Economica, París, 1986, pág. 127.

69 Sin embargo, como G. HeRMET pone de manifiesto, Rousseau, antropólogo del nuevo hombre, se ve atenazado por la duda. Lo cual no resulta extraño pues, el ginebrino, comparte con Platón el prejuicio de que uel fermento de la degradación y de la desunión no viene del Estado, sino del individuo, que porta este germen en sí mismon. El pueblo contra la democracia, Prólogo de Francisco Murillo Ferrol, Instituto de Estudios Económicos, Madrid, 1989, pág. 25. 
a la inversa, admitimos la persistencia del egoísmo en el modelo, su inoperancia está asegurada a convertirse el bien público en un ideal prácticamente inaccesible.

\section{El pueblo soberano como «multitud ciega» que precisa de líderes}

En la sociedad del Contrato, las decisiones más generales, las cuestiones importantes para la vida social, aquellas que más altura de miras y sacrificios precisan, requieren una decisión del colectivo. $Y$ sencillamente, porque para Rousseau, "sólo a los asociados corresponde reglamentar la sociedad" ${ }^{70}$. De ahí, que la soberanía del cuerpo político indivisible, inalienable, infalible y absoluta - resida en el pueblo reunido en asamblea.

Más adelante, empero, el mismo autor que había elevado el colectivo a la categoría de soberano, se pregunta: "Cómo una multitud ciega que con frecuencia ignora lo que quiere, porque raramente sabe lo que es bueno, llevará a cabo por sí misma una empresa tan grande y difícil como un sistema de legislación? El pueblo quiere siempre el bien, pero no siempre sabe verlo; la voluntad general es siempre recta, pero el juicio que la guía no siempre es claro. Preciso es hacer ver al pueblo los objetos tales como deben aparecerle; enseñarle el buen camino que busca, protegerle contra la seducción de las voluntades particulares (...). Todos necesitan igualmente de guías; preciso es obligar a unos a conformar su voluntad con su razón; preciso es, asimismo, enseñar al pueblo a conocer lo que desea. (...) Ved, pues, de dónde nace la necesidad de un legislador" ${ }^{71}$.

De la lectura de estas reflexiones se deduce que, paradójicamente, un pueblo capaz de encontrar de forma espontánea y unánime la sociedad perfecta, se ha vuelto de repente absolutamente ciego. Su súbita incompetencia le impide acometer la compleja tarea de legislar ${ }^{72}$. Pero, ¿acaso no era el pacto fundacional una emprea mucho más difícil que aprobar una ley? ${ }^{73}$. Si la voluntad general se manifestaba con evidencia

70 Contrato social, Libro II, Cap. VI, págs. 48 y 49; Halbwachs, pág. 172.

${ }^{71}$ Ibidem, Libro II, Cap. VI, pág. 48; Halbwachs, págs. 172 y 173.

72 Tarea que en otros lugares del Contrato social-como en las primeras líneas del Libro IV, Capítulo I- no le parece tan compleja, sino natural consencuencia de la armonía y vigor del Estado.

73 En este sentido, vid. A. Torres del Moral, "Modelo y antimodelo...", ya cit., págs. 143-146. 
en todas partes, ¿cómo de pronto se vuelve tan oscura? Si sólo el buen sentido bastaba para descubrirla, ¿porqué se precisa una persona de cualidades tan especiales para hacerlo ${ }^{74}$

Una vez más, el ginebrino se mueve entre dos sentimientos enfrentados. Por un lado, la exaltación pasional del colectivo fruto de la confianza y respeto que el pueblo le merece. Por otro, el recelo racional hacia el mismo, consecuencia, a su vez, del desprecio que por la "masa" siente. De esta forma, $y$ frente a un pueblo teórico que siempre quiere el bien y nunca se corrompe, Rousseau opone en la práctica otro que, siendo el mismo, cambia de naturaleza y se transforma en "multitud ciega". Reaparece asi el pueblo empírico en lugar del pueblo racional. Y el soberano, que por serlo era siempre lo que debía ser, se trasmuta en populacho.

Sólo determinando los casos en que tal mutación se produce será posible obtener la garantía que el cuerpo político precisa. Pero... ¿en qué momento la association deviene en agrégation? ¿Cuándo desaparece la reflexión y surge la incapacidad política? Y si ésta última es evidente y la "inteligencia superior" se hace necesaria, ¿quién asegura que el legislador no se equivoca e induce a error a la Asamblea? $O$ incluso peor, ¿cómo distinguir a éste de un sátrapa supuestamente adornado de facutlades mayéuticas? Imposible responder. La operatividad del modelo y la legitimidad de las decisiones colectivas, ya sean unánimes o mayoritarias, dependerá, de nuevo, de circunstancias inciertas. Presunciones de compleja verificación que convierten el concepto de voluntad general en una quimera abierta a cualquier manipulación plebiscitaria.

\section{La Ley de la Mayoría en los sufragios como sustituto inade- cuado de la supuesta unanimidad subyacente}

En la propuesta roussoniana, como sabemos, la unanimidad se erige, caso de expresar la voluntad general, en el objetivo legitimador del

74 En palabras de Rousseau, "(...) se necesitaría una inteligencia superior que conociera todas las pasiones de los hombres y que no experimentase ninguna; que no tuviese relación alguna con nuestra naturaleza y que la conociese a fondo". Alguien, "capaz de cambiar, por asi decirlo, la naturaleza humana; de transformar a cada individuo, que, por sí mismo, es un todo perfecto y solitario, en parte de un todo mayor..." (/bidem, Libro II, Cap. VII, págs 48 y 49; Halbwachs, págs. 179 y 180). En suma, un taumaturgo redentor adornado de lo que más tarde $\mathrm{M}$. Weber calificaria como autoridad carismática. 
sistema político. Pero como las más de las veces tal objetivo deviene inaccesible, Rousseau invoca lo que a su entender es un interprete privilegido de la volonté générale, un cualificado sucedáneo del consenso: la ley de la mayoría en los sufragios. En ese mismo instante, su modelo procedimental de legitimación queda abocado al fracaso. Y es que, la ley de la mayoría, por su dinámica intrínseca y por lo que conceptualmente representa, puede no expresar la unanimidad subyacente del cuerpo político. Por el contrario, y de forma mecánica, divide la Sociedad en dos opciones enfrentadas: la mayoritaria, que decide la cuestión debatida y vinculada al colectivo, y la minoritaria, de operatividad nula.

En el Contrato, sin embargo, la escisión social descrita no se produce ya que la mayoría es presentada teóricamente como una regla operativa carente de especificad propia. Como un instrumento idóneo que pretende compatibilizar el funcionamiento práctico del modelo y el marco legitimador del mismo. Su función es simple: no paralizar la acción pública y aprobar leyes en torno a las cuales no exista consenso manifiesto. $Y$ todo ello, sin contravenir la supuesta sociedad unánime; intentando preservar la libertad de autogobierno de cada uno de los votantes.

Para lograrlo, lo que Rousseau sugiere es un complejo y arriesgado argumento compuesto, en nuestra opinión, de tres proposiciones: dos en principio contradictorias, y una tercera que se deduce abstractamente de las anteriores y las concilia. Son las siguientes:

Primera. La voluntad general del soberano, que es también la de cada uno de los súbditos, vincula por convención a todos los miembros del cuerpo político. De esta forma, si tras el cómputo de los votos existe un determinado grupo de individuos disidentes con los que moralmente se considera voluntad general, es porque no fueron capaces de descubrirla en un primer momento. De serlo, hubieran opinado conforme a ella pues, al consentir el contrato y ser parte del colectivo la voluntad de éste debe ser en última instancia la suya y, por lo tanto, unánime.

Segunda. Una vez instituido el Estado, la aprobación de las leyes puede producirse con absoluta legitimidad a través de la regla mayoritaria. Al inicio, los ciudadanos convinieron que en el futuro, y a falta de consenso, las decisiones colectivas se adoptasen mayoritariamente. Por supuesta convención legítima, implícita nada menos que en el pacto social, admitieron la posibilidad de ser mayoría y minoría y, caso de pertenecer en un determinado sufragio a la segunda, se obligaron a respetar y someterse a la primera. Sometimiento, en principio, carente de fundamentación valorativa.

Tercera. Si las anteriores proposiciones (la voluntad general moralmente unánime obliga por convención al pueblo, y la opinión de los 
más obliga por convención a los menos) se le presentan a Rousseau como premisas lógicas perfectamente compatibles, es, precisamente, porque en la voluntad del mayor número reside el carácter esencial de la voluntad general.

Por ello, los ciudadanos disidentes con la opinión mayoritaria no sólo deben respetarla y someterse a ella. Caso de repetirse la votación, los menos, conscientes de su error al descubrir la opinión de la mayoría todos los caracters de la voluntad general, cambiarán el sentido de su voto y el nuevo resultado será unánime.

Pero... ¿porqué el mayor número expresa en esencia una voluntd que debiera manifestarse sólo por consenso? Evidentemente, tal afirmación no se extrae - como las proposiciones anteriores- por convención alguna, ni por una súbita fe en la indefectible racionalidad del mayor número, sino porque Rousseau presume que la mayoría absoluta es un adecuado sustituto de la unanimidad social, cuando ésta no puede alcanzarse o concluirse del silencio. Como los ciudadanos libres de pasiones tienden naturalmente hacia la verdad, le parece razonable que la opinión más numerosa tenga mayores probabilidades de expresar esta verdad supuestamente compartida por todos ${ }^{75}$.

El argumento, en nuestro opinión, no puede ser más falaz y menos convincente. $Y$ ello, por tres razones. En primer lugar, porque admitida la posibilidad de que algunos ciudadanos no sean capaces de descubrir la verdad, resulta imposible determinar con certeza cuándo la opinión más numerosa coincide con la de los ciudadanos alumbrados por ella. En segundo, pero no menos importante, porque los principios teóricos sobre los que la ley de la mayoría se asienta son diametralmente opuestos a los que la regla que pretende sustituir. Mientras la unanimidad se construye sobre bases individualistas, la mayoría presupone que el grupo constituye una unidad objetiva con voluntad propia siempre coincidente con la mayoritaria ${ }^{76}$. ¿Cómo entonces ha podido el pueblo convenir en un sólo acto la garantía de una sociedad unánime y su aparente contrario? Y sobre todo, ¿cómo presumir que ha sido así y que ambos principios, una vez vaciado teóricamente el segundo de contenido propio, son equivalentes? La única respuesta satisfactoria sólo puede encontrarse en otra

75 Esta idea, calificada por Bertrand dE Jouvenel como «el postulado de la convergencia», ha sido ampliamente analizada en su célebre obra De la souveraineté, librairie de Médicis, París, 1955, págs. 355 y sigs.

76 Vid. por todos, G. SIMMEL, sociología, l, Estudios sobre las formas de socialización. alianza Universidad, Madrid, 1986 (primera edición alemana de 1908), pág. 202 y sigs. 
presunción. En el ideal dificilmente alcanzable de la completa igualdad de los pactantes, o incluso mejor, del mantenimiento de esa igualdad en una comunidad de iguales. Sólo en ella -dice G. Vedel 7 -, los intereses de todos serían los mismos y la minoría, al carecer las diferencias de opinión de raíces profundas, podría reconocer en la voluntad mayoritaria la suya propia y la de la comunidad entera. Con esta presunción, o más bien, desideratum igualitario, «... Rousseau consigue resolver por su cuenta lo que podríamos llamar la antinomia fundamental de todo ideal democrático. La democracia se funda en la idea de libertad. Pero la libertad tiene dos caras. En el plano individual, significa que cada uno no obedece más que a él mismo, es decir que la mayoria gobierna. Es evidente que las dos caras se oponen: libertad de los individuos y poder absoluto de la mayoría. Pero, para Rousseau, la voluntad general es, en derecho, en una sociedad igualitaria, una voluntad unánime, no siendo las divergencias de opinión más que accidentes. Así pues, en definitiva, autodeterminación del individuo y autodeterminación del grupo se reconcilian ${ }^{78}$.

No obstante, constatadas por el propio Rousseau, la persistencia del egoísmo humano y de su vil interés, la crónica incompetencia de la masa y la inagotable ansia de poder de los magistrados, la ficción igualitaria y su supuesto trasunto electoral se destruyen; como también lo hace, curiosamente, la confianza en plena legitimidad del simple resultado unánime.

Y es que, como ya vimos con anterioridad, para legitimar las decisiones colectivas no bastaba con el consenso en torno a ellas. Este necesitaba ser, además, un fiel reflejo del espíritu colectivo. Cosa que, reconocidas las dificultades que existen para alumbrarlo, dependía, a su vez, de un conjunto de dudosas circunstancias. Pues bien, si incluso el consenso en las decisiones colectivas no garnatiza totalmente que éstas respondan al interés general y representen a la comunidad, tampoco podrá garantizarlo su sustituto por muy adecuado que éste sea ${ }^{79}$. Sobre todo, cuando se trata de un sustituto que, lejos de funcionar como tal, excluye

77 G. VEDEL, Droit constitutionnel, Sirey, Paris, 1949, págs. 193 y 194, para quien légalité es la clave explicativa de muchas paradojas roussonianas. En parecidos términos, pero años después, A. Hauriou, Droit constitutionnel et institutions politiques, 4ème édition (première edition de 1966), Montchrestien, París, 1970 , págs. 262 y sigs. De esta última, existe traducción al castellano de J.A. González Casanova, editorial Ariel, Barcelona, 1971, págs. 256 y sigs.

${ }_{78}$ G. Vedel, Op. cit., pág. 194.

79 En gráficas palabras de F. RANGEON, "puesto que una suma, incluso total de intereses particulares no da el interés común, con mayor motivo, una suma simplemente mayoritaria lo da todavía menos". L'idéologie de l'intérêt général, ya cit., pág. 124. 
por propia definición el concepto que pretende sustituir y divide la supuesta sociedad unánime en el mismo instante de su aplicación en la Asamblea. Escisión social, con la que nos adentramos en el tercer motivo que ratifica el espurio carácter de la mayoría roussoniana.

Como H. Kelsen puso de manifiesto en Esencia y valor de la democracia, el sentido del principio mayoritario, tras un análisis fundado en la realidad social, no consiste tanto en que triunfe la voluntad del mayor número, "sino en aceptar la idea de que bajo la acción de este principio, los individuos integrantes de la comunidad (...) se dividan en dos grupos fundamentales" ${ }^{80}$.

Es obvio que en el Contrato, escrito siglo y medio antes que el célebre opúsculo del jurista austriaco, la mayoría propuesta no presenta los mismos contornos. Por supuesto, su autor no es del todo ajeno a la posible división social que el desenvolvimiento práctido de la misma conlleva; pero sí lo es de las naturales causas que pueden originar dicha división y de sus eventuales y positivas consecuencias. $Y$ ello, porque el ginebrino desconoce el auténtico sentido del pluralismo, al igual que el democrático valor del conflicto. De ahí que, en su opinión, la discrepancia política y su correlato eletoral, lejos de constituir una fuerza de integración social ${ }^{81}$, sean indicios inequívocos de la ineluctable decadencia del Estado.

Ocurre, sin embargo, que a pesar de la idealidad y asepsia conflictual del modelo pergeñado, el autor del Contrato reconoce que el ciudadano, en sus actuaciones públicas, realiza con frecuencia un cálculo egoísta de las ventajas que puede obtener de la colectividad. Para lograrlas, apenas cuenta con un recurso legítimo: su voto, o mejor dicho, -lo que ya no es tan legítimo- la utilización interesada del mismo. Un recurso que verá limitada su influencia sobre la decisión final en proporción inversa al número de ciudadanos que compongan la asamblea. Precisamente por ello, el deso del individuo egoísta consiste en aumentar su influencia, para lo cuál se asociará a otras voces de parecido interés formando sociedades estables.

${ }^{80}$ H. KELSEN, Esencia y valor de la democracia, Guadarrama, Ed. Labor, Barcelona, 1977, pág. 84.

81 Recordemos que, para KELSEN, lo que caracterizaba sociológicamente al principio de la mayoría era precisamente esa fuerza de integración social, ya que, "al quedar agrupada en dos sectores esenciales la totalidad de los ciudadanos" brotaba «la posibilidad del convenio o transacción para la formación de la voluntad colectiva". Transacción que para el iuspublicista austriaco era "la verdadera aproximación a la unanimidad exigida por la idea de libertad en la creación del orden social por los sujetos al mismon. Op. cit., págs. 84-86 y 97. 
Lejos de la moderna concepción sociológica, Rousseau concibe a estos grupos o sociedades de forma excluyente. Cada súbdito sólo podrá participar al mismo tiempo en una asociación, cuya voluntad se convertirá en general respecto a sus miembros al actuar ésta en función de sus propios intereses ${ }^{82}$. Así, cuando en la asamblea llegue el momento de ejercer el sufragio, se podrá decir que no habrá ya "tantos votantes como hombres, sino tantos como asociaciones» ${ }^{83}$. Por la dinámica intrínseca de la regla mayoritaria - de la que, como dijimos, Rousseau no es ajeno-, es perfectamente factible que los grupos establecidos, en vez de disolverse, se cristalicen y formen dos bloques antagónicos. Cada uno de ellos intentará prevalecer sobre el otro hasta que su opinión, tras obtener el respaldo mayoritario, decida la cuestión debatida a su favor. Cuando una de esas sociedades parciales alcance dicho poder de forma continuada, ya no se manifestará la voluntad general, siendo la opinión del mayor número la voluntad particular dominante ${ }^{84}$. En ese preciso instante, el lazo social, el bien público, las leyes, el Estado mismo no existirán ya sino de forma ilusoria y vana.

Evidentemente, el iter descrito no es automático e inexorable, y por lo tanto, el presumible resultado al que aboca acaso no se produzca. Pero, si bien es cierto que la fracción mayoritaria obtenida tras el cómputo de los votos puede revelar, de forma accidental y momentánea, coyunturales divergencias de punto de vista y variar en cada escrutinio, lo más frecuente es que la opinión del mayor número exprese la consolidación de una voluntad parcial y, por contra, se cristalice. Mientras en el primer caso cabrá todavía la posibilidad de vincular el resultado con la supuesta unanimidad subyacente y la voluntad general del cuerpo político, en el segundo, ésto no será ya posible.

Por desgracia, cualquier intento de determinar la situación en que la asamblea se encuentra resultará baldio, pues no existe posibilidad alguna de establecer correspondencia fiable entre el interés del ciudadano y su voto. Al carecer de la certeza necesaria sobre lo que el resultado mayoritario representa, la ley de la mayoría en los sufragios no podrá ser adecuado

${ }_{82}$ El proceso es descrito por Rousseau con las siguientes palabras: "Si cuando, informado suficientemente, delibera el pueblo, no tuviesen los ciudadanos comunicación entre sí, del gran número de pequeñas diferencias, resultaría siempre la voluntad general y la deliberación sería siempre buena. Pero cuando se forman pandillas y asociaciones parciales a expensas de la total, la voluntad de cada una de estas asociaciones se convierte en general respecto de sus miembros $y$ particular respecto del Estado". Contrato social, Libro II, Cap. III, pág. 39; Halbwachs, págs. 145 y 146.

83 Ibidem, Libro II, Cap. III, pág. 39; Halbwachs, pág. 146.

84 Vid. P. FaVre, art. cit., págs. 157 y sigs. 
sustituto de la unanimidad social, sino recurso práctico para la adopción de decisiones colectivas altamente discutibles y generalmente ilegítimas.

\section{A MODO DE CONCLUSIÓN}

A lo largo de las anteriores reflexiones hemos podido comprobar que el modelo procedimental roussoniano presenta incongruencias y tensiones diversas. Si en su formulación abstracta los mecanismos propuestos por el ginebrino resultaban de una gran fuerza lógica, es al desarrollar éstos en una sociedad real cuando surgen las contradicciones que desnaturalizan el modelo. No podía ser de otra manera pues, el concepto clave de todo el constructo, la voluntad general, además de previa e inmanente, debía manifestarse sufragio tras sufragio en las asambleas del pueblo.

De ahí, que la legitimidad de todas las actuaciones públicas y decisiones colectivas no pueda derivar sino de su correspondencia con la abstracta voluntad general; y sólo en aquellas ocasiones en las que animado del espíritu social el soberano responda de forma unánime, tal correspondencia será, en principio, perfecta. $Y$ decimos en principio, porque, aunque Rousseau presenta la sociedad consensual como la máxima garantía del ciudadano que le induce a consentir el contrato, reconoce que las manifestaciones realmente unánimes son proco frecuentes. En su defecto, pero manteniendo la unanimidad como exigencia moral, propone el consentimiento tácito y la regla mayoritaria. La paradoja está servida.

En primer lugar, la declaración de voluntad del soberano, que debía ser expresa para ser legítima, se presume en algunas ocasiones de su contrario: el silencio. En segundo, la legitimación de una sociedad que debía ser unánime, recae ahora en la ley de la mayoría, sustituto de la unanimidad que se presume idóneo al reflejar la supuesta esencia de la voluntad general. En este caso, el sofisma es aún mayor. $Y$ ello, porque, en nuestra opinión, Rousseau confunde lo que Elías Díaz advierte que nunca debe confundirse hablando de legitimidad democrática: «por un lado, la vía para llegar a ella, la regla de decisión, el cirterio operativo para crear y orientar el Derecho positivo (...); por otro, el contendio concreto, jurídico-político de tal decisión, y, finalmente, (...) el siempre problemático criterio de la verdad o justicia de tal decisión” ${ }^{85}$. En su incensante

85 Vid. Elías DíAz: De la maldad estatal y la soberanía popular, Debate, Madrid, 1984, pág. 60. 
búsqueda del más elevado rango en la escala de valores políticos, el autor del Contrato intenta hacer coincidir los tres extremos en uno solo. Pero de esta forma, la mayoría propuesta resulta tan especulativa que poco o nada tiene que ver con lo que el principio y la regla mayoritaria suponen realmente.

Y es que, la ley de la mayoría de los sufragios, lejos de ser elemento auxiliar de la unanimidad implícita, contradice la base individualista de la misma y divide la sociedad en bloques antagónicos. Por su significado y desenvolvimiento práctico, no permite representar más que la voluntad dominante del mayor número.

Pero incluso en el supuesto de que la opinión de los más pudiera tomarse en el fondo por opinión unánime, las contradicciones admitidas en el modelo viciarían de raíz la pretendida correspondencia con la voluntad general. La incapacidad política, el egoísmo humano, la servidumbre del pueblo $y$ los actos de aclamación podrían transformar la decisión colectiva en algo carente de contenido legítimo cierto. El resultado reflejaría el egoísmo, la incompetencia o el servilismo de mayor número, pero nunca la voluntad general ${ }^{86}$.

En conclusión, la unanimidad legitimadora resulta - la más de las veces-inalcanzable, y de lograrse en algún instante, sumamente sospechosa. Su inadecuado sustituto no corre mejor suerte y deviene, en el mejor de los casos, en mero instrumento operativo tendente a evitar la paralización del Estado. El fracaso práctico teórico resulta inevitable. Y como sus presunciones no pasan del mundo de lo abstracto, la difícil ecuación entre poder y libertad, la irreductible tensión entre lo individual y lo colectivo propia del Estado moderno, continúa.

${ }^{86}$ ¿Qué hacer en este instante? Si la identidad entre comunidad y mayoría -clave del constructo-se muestra ilusoria, ¿qué debe hacer el ciudadano honesto? ¿Debe seguir a la volonté générale, o a la volonté de tous? Para Groethursen, la paradoja se prolonga a la respuesta pues, en su opinión, "cada una de estas alternativas implica la violación de uno de los dos principios sobre los que reposa todo el sistema de libertades públicas en Rousseau. Si por obedecer a la voluntad general - continúa en primera persona-, me siento obligado a desobedecer la voluntad de todos, ¿qué va a ser de mi derecho de ciudadano, o mejor todavía del derecho que tienen todos mis conciudadanos a a hacer valer su voluntad? Pero, por otra parte, si conformándome con las decisiones tomadas por la mayoría, actuó en contra de los mandatos de la voluntad general, ¿no es ésto sacrificar la cosa pública?". Op. cit. pág. 97. 